\title{
Inflammatory Bowel Disease-Specific Autoantibodies in HLA-B27-Associated Spondyloarthropathies: Increased Prevalence of ASCA and pANCA
}

\author{
H.-P. Török ${ }^{a, b} \quad$ J. Glas ${ }^{a} \quad$ R. Gruber ${ }^{a} \quad$ V. Brumberger ${ }^{a} \quad$ C. Strasser ${ }^{a}$ \\ H. Kellnera E. Märker-Hermann ${ }^{c}$ C. Folwacznya,b
}

a Medizinische Poliklinik, ${ }^{b}$ Chirurgische Klinik und Poliklinik, Standort Innenstadt, Ludwig-Maximilians-Universität, München, und ' Klinik Innere Medizin IV, Dr.-Horst-Schmidt-Kliniken, Wiesbaden, Deutschland

\section{Key Words}

ASCA $\cdot$ pANCA $\cdot$ PAB $\cdot$ HLA-B27 · Spondyloarthropathy ·

Crohn'sdisease $\cdot$ Ulcerative colitis

\begin{abstract}
Aims: An association between inflammatory bowel disease (IBD) and spondyloarthropathies (SpA) has repeatedly been reported. The aim of the present study was to investigate whether serologic markers of IBD, e.g. antibodies against Saccharomyces cerevisiae (ASCA), antibodies against exocrine pancreas (PAB) and perinuclear antineutrophil cytoplasmic antibodies (pANCA) are present in HLA-B27-associated SpA. Methods: 87 patients with HLA-B27-positive SpA and 145 controls were tested for ASCA, PAB and pANCA employing ELISA or indirect immunofluorescence, respectively. Antibody-positive patients were interviewed regarding IBD-related symptoms using a standardized questionnaire. Results/Conclusion: When compared to the controls, ASCA IgA but not ASCA lgG levels were significantly increased in patients with $\mathrm{SpA}$, in particular in ankylosing spondylitis (AS) and undifferentiated SpA (uSpA). pANCA were found in increased frequency in patients with SpA whereas PAB were not detected. The
\end{abstract}

existence of autoantibodies was not associated with gastrointestinal symptoms but sustains the presence of a pathophysiological link between bowel inflammation and SpA.

Copyright $@ 2004$ S. Karger AG, Basel

\section{Introduction}

Crohn's disease (CD) and ulcerative colitis (UC) are associated with peripheral and axial arthropathies [1-4]. The findings of several studies have suggested that a substantial number of patients with spondyloarthropathies (SpA) may have asymptomatic intestinal inflammation, usually affecting the ileum [5-14]. A further development of CD or UC was observed in about $7 \%$ of these patients [8]. The pattern of joint and spine involvement in patients with inflammatory bowel disease (IBD) and in classic SpA such as ankylosing spondylitis can be similar. Thus, it has been hypothesized that the intestinal inflammation might be of pathogenic relevance for the development of arthritis and that the ileal inflammation in SpA could represent a pre- or subclinical form of CD.

In IBD, various autoantibodies have been described and are considered as serological markers for CD or UC.

\begin{tabular}{ll}
\hline KARGER & ( 2004 S. Karger AG, Basel \\
Fax +4161306 1234 & 0012-2823/04/0701-0049\$21.00/0 \\
$\begin{array}{l}\text { E-Mail karger@karger.ch } \\
\text { www.karger.com }\end{array}$ & $\begin{array}{l}\text { Accessible online at: } \\
\text { www.karger.com/dig }\end{array}$
\end{tabular}

PD Dr. med. Christian Folwaczny
Medizinische Poliklinik, Ludwig-Maximilians-Universität München
Nussbaumstrasse 20, DE-80336 München (Germany)
Tel. +49 895160 2625, Fax +49 8951604187

E-Mail christian.folwaczny@medinn.med.uni-muenchen.de 
Table 1. Characteristics of the study population

\begin{tabular}{lllllll}
\hline & \multicolumn{3}{l}{ Spondyloarthropathies } & & & \multicolumn{2}{c}{$\begin{array}{l}\text { Control } \\
\text { individuals }\end{array}$} \\
\cline { 2 - 5 } & AS & ReA & PsA & USpA & $\begin{array}{l}\text { all patients } \\
\text { with SpA }\end{array}$ & \\
\hline Patients & 51 & 8 & 9 & 19 & 87 & 145 \\
Male/female ratio & $37 / 14$ & $4 / 4$ & $8 / 1$ & $13 / 6$ & $62 / 25$ & $71 / 74$ \\
Age, years (mean \pm SD) & $39.4 \pm 1.1$ & $44.8 \pm 13$ & $36 \pm 14.4$ & $34.4 \pm 1.2$ & $38.5 \pm 11.8$ & $44.6 \pm 12.5$ \\
Age, years (range) & $24-70$ & $21-63$ & $18-65$ & $19-54$ & $18-70$ & $18-68$ \\
\hline
\end{tabular}

Anti-Saccharomyces cerevisiae antibodies (ASCA) appear in approximately two thirds of CD patients [15-17], whereas antibodies against exocrine pancreas (PAB) are present in about one third of the patients $[18,19]$. These antibodies are highly specific for IBD. Perinuclear antineutrophil cytoplasmatic antibodies (pANCA) are found in $45-80 \%$ of patients with UC [20, 21]. Familial clustering of these antibodies has been described, with an increased prevalence among first-degree relatives of patients with IBD [22-26]. Considering that first-degree relatives of IBD patients display a 10- to 15 -fold increased risk of developing either CD or UC throughout their lifetime, these observations are compatible with a role of the respective antibody as a preclinical marker of IBD.

An increased prevalence of antibodies with a close correlation to IBD in patients with SpA could represent an additional pathophysiological link between both disease entities. Therefore, in the present study we investigated if IBD-associated autoantibodies, e.g. ASCA, pANCA and $\mathrm{PAB}$, are present in HLA-B27-associated SpA and if the presence of these antibodies correlates with clinical symptoms suggestive for IBD.

\section{Patients and Methods}

\section{Study Population}

The study population comprised 145 healthy unrelated blood donors and 87 patients with HLA-B27-positive SpA (51 patients with ankylosing spondylitis (AS), 8 with reactive arthritis (ReA), 9 with psoriatic arthritis (PsA) and 19 with undifferentiated SpA (uSpA)). Cases with a previous diagnosis of CD or UC were excluded. All patients had previously been tested for HLA-B27. The baseline characteristics of the study population are depicted in table 1 . Sera were obtained by centrifugation of venous whole blood samples and stored at $-20^{\circ} \mathrm{C}$ until use.

Patients who were tested positive for autoantibodies were interviewed regarding IBD-related symptoms and manifestations using a standardized questionnaire. The following parameters were assessed: stool frequency ( $\leq 3$ or $>3$ per day), anal discharge of mucus or blood, abdominal pain, weight loss and dermal or ocular lesions. Additionally, information about a positive family history of IBD, previous endoscopic or radiological findings and consumption of non-steroidal anti-inflammatory drugs (NSAIDs) were obtained.

\section{Enzyme-Linked Immunosorbent Assays (ELISA) for ASCA}

Sera of patients and controls were tested for both ASCA IgA and IgG using Medizym ${ }^{\circledR}$ ASCA IgA and Medizym ${ }^{\circledR}$ ASCA IgG ELISA kits (Medipan Diagnostica, Selchow, Germany). Briefly, $100 \mu \mathrm{l}$ of serum and control samples diluted $1 / 51$ in the ready-for-use diluent were added to 96 -well microtiter plates coated with the specific antigen (mannan from $S$. cerevisiae). After $60 \mathrm{~min}$ incubation at $37^{\circ} \mathrm{C}$ the unbound serum components were removed, the plates were washed and then $100 \mu \mathrm{l}$ of anti-human IgA or IgG antibodies conjugated with horseradish peroxidase were added to each well. The plates were washed again and $100 \mu \mathrm{l}$ of substrate containing hydrogen peroxide were added. After $10 \mathrm{~min}$ the enzyme reaction was stopped by adding $100 \mu \mathrm{l}$ of stop solution and the plates were read at 450 vs. $620 \mathrm{~nm}$ using a microplate reader. Diluted human sera provided by the manufacturer served as internal controls. For qualitative evaluation, the binding index $\left(\mathrm{BI}=\mathrm{OD}_{\text {sample }} / \mathrm{OD}_{\text {cut-off control }}\right)$ was calculated. The cut-off control for the IgA assay was the $20 \mathrm{U} / \mathrm{ml}$ calibrator, whereas for the IgG assay the cut-off control was provided. The sample was considered positive at a BI of $\geq 1.0$. For every sample, two independent analyses on the same plate were carried out and the mean of the two analyses was used in further evaluations.

\section{Indirect Immunofluorescence (IIF)}

Antineutrophil cytoplasmic antibodies (ANCA) and PAB were visualized by standard IIF as described in detail elsewhere [19]. Briefly, sera were diluted 1:10 in phosphate-buffered saline with $0.2 \%$ Tween and tested for ANCA on commercially available glass slides containing three Biochips for each sample with ethanol-fixed neutrophils, formalin-fixed neutrophils and monkey liver cryostat sections (Euroimmun AG, Lübeck, Germany), allowing differentiation of ANCA patterns from antinuclear antibodies patterns. For the detection of $\mathrm{PAB}$, Biochips with monkey pancreas cryostat sections mounted on glass slides (Euroimmun AG) were employed. Fluorescein-conjugated goat antihuman IgG was used as secondary antibody, according to the manufacturer's instructions. The immunofluorescence patterns were assessed under a fluorescence microscope by two independent investigators. The pANCA titer was determined using progressive dilutions of the positive sera up to 1:1,000. 


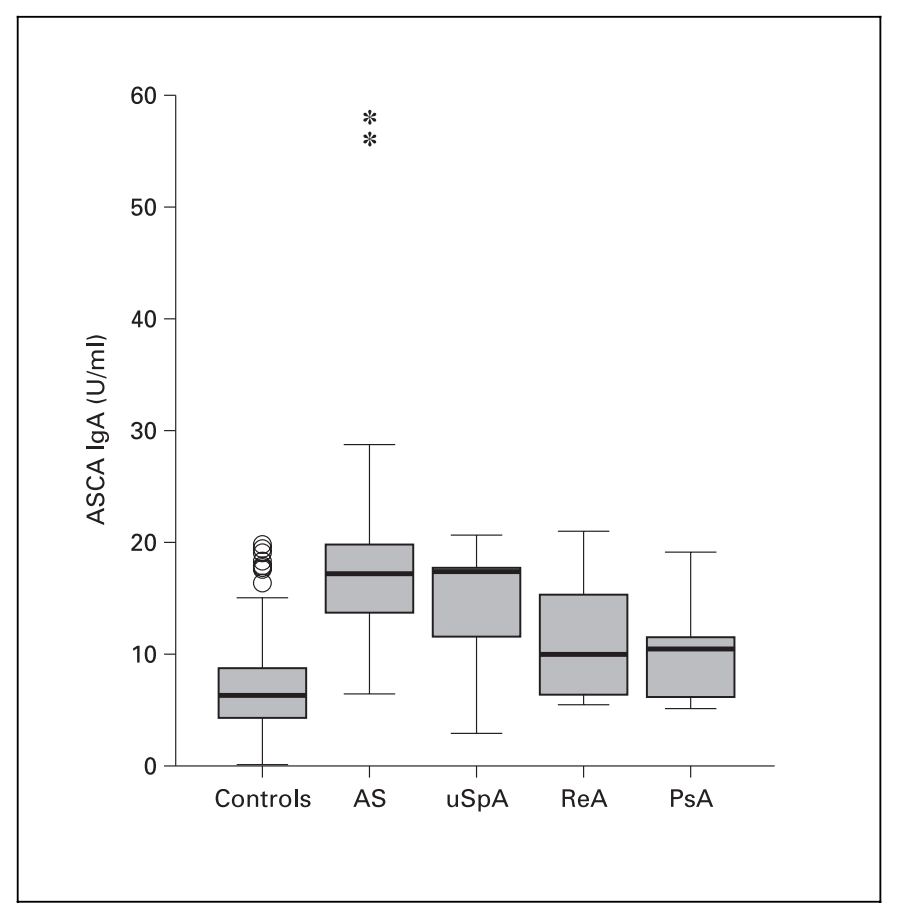

Fig. 1. ASCA IgA levels in controls and patients with HLA-B27-positive SpA. * Correspond to 56 and $270 \mathrm{U} / \mathrm{ml}$, respectively.

\section{ELISA for ANCA Antigen Specificity}

All IIF pANCA-positive sera were investigated for six common antigen specificities: proteinase 3, myeloperoxidase, elastase, cathep$\sin \mathrm{G}$, lactoferrin and bactericidal/permeability increasing protein (BPI) using a commercially available ELISA kit (ANCA-Profil (IgG), Euroimmun AG), according to the manufacturer's instructions.

\section{Statistics}

The ASCA concentrations in the different groups were compared employing the Mann-Whitney $U$ test. Categorical variables were compared using Fisher's exact test. p values $<0.05$ were considered significant. The statistical analysis was performed using SPSS software.

\section{Results}

\section{$A S C A \operatorname{Ig} A$ and $A S C A \operatorname{Ig} G$}

ASCA IgA levels were significantly higher in patients with HLA-B27-associated SpA than in healthy controls $(\mathrm{p}<0.0001)$ (fig. 1). When the group of patients with SpA was divided into clinical subgroups, significantly higher ASCA IgA levels were observed in patients with AS and $\mathrm{uSpA}(\mathrm{p}<0.0001)$ whereas in patients with ReA and PsA, levels were only slightly increased compared to healthy controls $(\mathrm{p}<0.05)$. At the qualitative evaluation, using

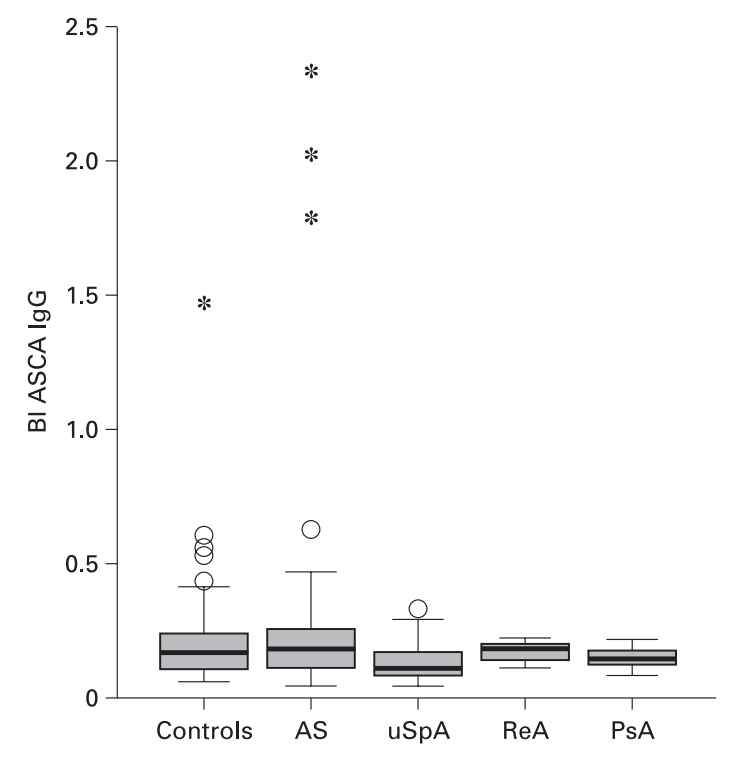

Fig. 2. ASCA IgG levels in controls and patients with HLA-B27 SpA: $\mathrm{BI}=$ binding index $=\mathrm{OD}_{\text {sample }} / \mathrm{OD}_{\text {cut-off control }}$.

the cut-off of $20 \mathrm{U} / \mathrm{ml}, 5$ patients with AS tested positive whereas all patients with ReA, PsA or uSpA and controls were negative $(\mathrm{p}<0.01)$.

The ASCA IgG concentrations were not significantly different in patients with $\mathrm{SpA}$ when compared to the controls (fig. 2). Using the cut-off supplied by the manufacturer, 2 patients with AS (1 of them also positive for ASCA IgA) and 1 control were positive for ASCA IgG. The combined frequency for ASCA IgA and ASCA IgG was significantly increased in patients with AS when compared to the controls $(\mathrm{p}<0.001)$.

\section{pANCA}

Four patients with HLA-B27-positive SpA (2 with AS and 2 with $\mathrm{uSpA}$ ) but none of the controls were ANCApositive in IIF $(\mathrm{p}<0.05)$. All ANCA-positive sera gave a perinuclear fluorescence pattern (pANCA). The pANCA titer was $1: 10$ in 2 cases, 1:100 in 1 case and 1:320 in 1 case. When tested in ELISA for the six common antigen specificities (proteinase 3, myeloperoxidase, elastase, cathepsin G, lactoferrin and BPI), none of the four IIF pANCA-positive sera was positive. 


\section{$P A B$}

PAB were not detected in any of the controls or the patients with $\mathrm{SpA}$.

\section{Clinical Data}

When interviewed using the standard questionnaire, symptoms or signs suggestive of IBD were not reported by any of the antibody-positive patients. A familial history of IBD was also not reported. Ileocolonoscopy had been performed in only 2 of the patients, in both cases 3 years before collection of the sera and no changes suggestive for IBD had been observed. Six of the 11 antibody-positive patients received NSAIDs at the time of blood sampling, 4 of them were positive for ASCA and 2 positive for pANCA.

\section{Discussion}

Herein we report an increased frequency of IBD-specific autoantibodies in patients with HLA-B27-associated SpA. Compared to healthy controls, the levels of ASCA IgA were significantly increased in patients with $\mathrm{SpA}$, in particular in the group of patients with AS and uSpA. At the qualitative evaluation using the cut-off control $20 \mathrm{U} /$ $\mathrm{ml}$, as suggested by the manufacturer for the diagnosis of $\mathrm{CD}, 5$ patients with AS tested positive but none of the controls or patients with other $\operatorname{SpA}(\mathrm{p}<0.01)$. However, the cut-off $20 \mathrm{U} / \mathrm{ml}$ for the Medizym ${ }^{\circledR}$ ASCA IgA kit might be too high for detecting AS, yielding a sensitivity of $13.7 \%$ at a specificity of $100 \%$. A lower cut-off for this kit was also suggested for the diagnosis of CD [17]. Moreover, a recent study detecting ASCA IgA in AS and uSpA suggested a cut-off of $11 \mathrm{U} / \mathrm{ml}$ [28]. Using this cut-off, the sensitivity for the diagnosis of AS or uSpA in our study yielded $83 \%$ by a specificity of $87 \%$. A cut-off of $15 \mathrm{U} / \mathrm{ml}$ gave a sensitivity of $70 \%$ for AS or uSpA at a specificity of 94\%. The levels of ASCA IgG were not raised in SpA. Two patients with AS and 1 control tested positive at the qualitative evaluation.

An increased frequency of pANCA in patients with $\mathrm{SpA}$ was also observed. Two patients with AS and 2 patients with uSpA but none of the controls tested positive for pANCA. However, this frequency is low compared to the reported frequencies for pANCA in UC $(>40 \%)$ [20, 21]. When employed in ELISA, six common antigen specificities (proteinase 3 , myeloperoxidase, elastase, cathepsin G, lactoferrin and BPI) were not bound by the four pANCA-positive sera. In two sera the titer might have been too low for a positive result in the ELISA
(1:10). However, as two sera exhibited fairly high titers, these findings could be compatible with a distinct antigen specificity which was not assessed by the ELISA. In contrast to ASCA and PAB, ANCA are not exclusively found in UC but are also seromarkers for other disease entities such as vasculitic disorders or primary sclerosing cholangitis. The immunofluorescence pattern and the respective ANCA target antigens in UC generally differ from those observed in vasculitis disorders. Data in the literature regarding the presence of ANCA in HLA-B27-associated disorders are scarce and contradictory. However, occurrence of ANCA was sporadically observed in patients with AS [29, 30], ReA [31], or anterior uveitis [32]. Data regarding intestinal involvement or IBD-related symptoms in antibody-positive patients are lacking in these studies.

Based on the available literature data it appears possible that the presence of IBD-specific autoantibodies represents yet undiagnosed cases of CD or UC in patients with $\mathrm{SpA}$. Although antibody-positive patients denied any suggestive symptoms, pre- or subclinical IBD is not excluded. Because endoscopy was not performed prospectively we cannot rule out that such cases might have been missed. Noteworthy, apart from the 5 AS patients with titers $>20 \mathrm{U} / \mathrm{ml}$, the serum levels for ASCA IgA were significantly higher in SpA compared to the controls. Literature data about the prevalence of concomitant ileocolitis in SpA are inconsistent due to different diagnostic methods such as scintigraphy by ${ }^{99 m}$ Tc leukocytes [33] or retrospective endoscopic findings [5-14]. Interestingly, the latter reported histologic abnormalities in up to $28 \%$ of healthy controls [34]. Furthermore, a recent study failed to demonstrate an association between the ASCA IgA levels and histologically confirmed bowel inflammation or the number of lymphoid follicles in gut biopsy specimens from patients with AS and uSpA [28]. Some cases of ileitis or colitis in SpA might have been caused by the administration of NSAIDs. The latter impair the integrity of the intestinal mucosa which could facilitate contact of luminal (bacterial or yeast) antigens with antigen-presenting cells. This mechanism was also proposed for expression of disease-specific autoantibodies in IBD [35]. However, increased intestinal permeability in $\mathrm{CD}$ patients does not associate with the ASCA status [35]. In addition, in patients with AS, subclinical gut inflammation and increased intestinal permeability have also been reported independent from the use of NSAIDs [36]. In the present study, 6 of the 11 ASCA- or pANCA-positive patients received NSAID therapy. $\overline{52} \quad \overline{\text { Digestion 2004;70:49-54 }}$
Török/Glas/Gruber/Brumberger/Strasser/ Kellner/Märker-Hermann/Folwaczny 
The increased frequency of IBD-specific antibodies lends some further credibility to the notion that the ileitis in HLA-B27-associated SpA and in CD might be pathophysiologically related. A similar immunologic background in SpA and IBD is supported by various observations [for overview, see 37], such as an upregulation of the adhesion molecule E-cadherin [38], an increase in the number of lymphoid follicles [39], a predominant Th1 cytokine profile [40] or the presence of macrophages expressing the scavenger receptor CD163 [41] in intestinal mucosa, which were demonstrated not only in CD but also in HLA-B27-associated rheumatologic diseases. Recently, an identical T-cell expansion in the colonic mucosa and the synovium of a patient with reactive spondyloarthropathy was also described [42].

Future trials might focus on the following topics: patients with $\mathrm{SpA}$ should be offered a prospective ileocolonoscopy and the prevalence of mucosal inflammatory changes should be compared between ASCA- or pANCApositive and -negative patients. Moreover, mucosal permeability should be assessed in order to provide a possible explanation for the presence of these antibodies in patients with normal endoscopic findings. Data should be compared after stratification of patients with respect to the use of NSAIDs. Finally, long-term observation of the patients could reveal if the presence of serum autoantibodies such as ASCA or pANCA is a predictive marker for subsequent development of an IBD or is rather an independent phenomenon in SpA.

\section{Acknowledgement}

The authors gratefully acknowledge the technical support of M. Siwy.

\section{References}

1 De Vlam K, Mielants H, Cuvelier C, De Keyser F, Veys EM, De Vos M: Spondyloarthropathy is underestimated in inflammatory bowel disease: Prevalence and HLA association. J Rheumatol 2000;27:2860-2865.

2 Salvarani C, Vlachonikolis IG, van der Heijde DM, Fornaciari G, Macchioni P, Beltrami M, Olivieri I, Di Gennaro F, Politi P, Stockbrugger RW, Russel MG: European Collaborative IBD Study Group: Musculoskeletal manifestations in a population-based cohort of inflammatory bowel disease patients. Scand J Gastroenterol 2001;36:1307-1313.

3 Palm O, Moum B, Ongre A, Gran JT: Prevalence of ankylosing spondylitis and other spondyloarthropathies among patients with inflammatory bowel disease: A population study (the IBSEN study). J Rheumatol 2002;29:511-515.

4 Steer S, Jones H, Hibbert J, Kondeatis E, Vaughan R, Sanderson J, Gibson T: Low back pain, sacroiliitis, and the relationship with HLA-B27 in Crohn's disease. J Rheumatol 2003;30:518-522.

5 Leirisalo-Repo M, Turunen U, Stenman S, Helenius P, Seppala K: High frequency of silent inflammatory bowel disease in spondylarthropathy. Arthritis Rheum 1994;37:23-31.

6 Mielants H, Veys EM, Cuvelier C, de Vos M: Ileocolonoscopic findings in seronegative spondyloarthropathies. Br J Rheumatol 1988;27: 95-105.

7 Mielants H, Veys EM, De Vos M, Cuvelier C, Goemaere S, De Clercq L, Schatteman L, Elewaut D: The evolution of spondyloarthropathies in relation to gut histology I. Clinical aspects. J Rheumatol 1995;22:2266-2272.
8 De Vos M, Mielants H, Cuvelier C, Elewaut A, Veys E: Long-term evolution of gut inflammation in patients with spondyloarthropathy. Gastroenterology 1996;110:1696-1703.

9 Mielants H, Veys EM, Cuvelier C, De Vos M, Goemaere S, De Clercq L, Schatteman L, Gyselbrecht L, Elewaut D: The evolution of spondyloarthropathies in relation to gut histology. III. Relation between gut and joint. J Rheumatol 1995;22:2279-2284.

10 De Vos M, Cuvelier C, Mielants H, Veys E, Barbier F, Elewaut A: Ileocolonoscopy in seronegative spondylarthropathy. Gastroenterology 1989;96:339-344.

11 Porzio V, Biasi G, Corrado A, De Santi M, Vindigni C, Viti S, Bayeli PF, Marcolongo R: Intestinal histological and ultrastructural inflammatory changes in spondyloarthropathy and rheumatoid arthritis. Scand J Rheumatol 1997;26: 92-98.

12 Simenon G, Van Gossum A, Adler M, Rickaert F, Appelboom T: Macroscopic and microscopic gut lesions in seronegative spondyloarthropathies. J Rheumatol 1990;17:1491-1494.

13 Lee YH, Ji JD, Kim JS, Bak YT, Lee CH, Kim $\mathrm{CH}$, Chae YS, Song GG: Ileocolonoscopic and histologic studies of Korean patients with ankylosing spondylitis. Scand J Rheumatol 1997; 26:473-476.

14 Grillet B, de Clerck L, Dequeker J, Rutgeerts P, Geboes K: Systematic ileocolonoscopy and bowel biopsy study in spondylarthropathy. Br J Rheumatol 1987;26:338-340.

15 Main J, McKenzie H, Yeaman GR, Kerr MA, Robson D, Pennington CR, Parratt D: Antibody to Saccharomyces cerevisiae (bakers' yeast) in Crohn's disease. BMJ 1988;297: 1105-1106.
16 Quinton JF, Sendid B, Reumaux D, Duthilleul P, Cortot A, Grandbastien B, Charrier G, Targan SR, Colombel JF, Poulain D: Anti-Saccharomyces cerevisiae mannan antibodies combined with antineutrophil cytoplasmic autoantibodies in inflammatory bowel disease: Prevalence and diagnostic role. Gut 1998;42:788791.

17 Ruemmele FM, Targan SR, Levy G, Dubinsky M, Braun J, Seidman EG: Diagnostic accuracy of serological assays in pediatric inflammatory bowel disease. Gastroenterology 1998;115: 822-829.

18 Stocker W, Otte M, Ulrich S, Normann D, Finkbeiner H, Stocker K, Jantschek G, Scriba PC: Autoimmunity to pancreatic juice in Crohn's disease. Results of an autoantibody screening in patients with chronic inflammatory bowel disease. Scand J Gastroenterol 1987; 139:41-52.

19 Folwaczny C, Noehl N, Endres SP, Loeschke $\mathrm{K}$, Fricke $\mathrm{H}$ : Antineutrophil and pancreatic autoantibodies in first-degree relatives of patients with inflammatory bowel disease. Scand J Gastroenterol 1998;33:523-528.

20 Duerr RH, Targan SR, Landers CJ, Sutherland LR, Shanahan F: Anti-neutrophil cytoplasmic antibodies in ulcerative colitis. Comparison with other colitides/diarrheal illnesses. Gastroenterology 1991;100:1590-1596.

21 Cambridge G, Rampton DS, Stevens TR, McCarthy DA, Kamm M, Leaker B: Anti-neutrophil antibodies in inflammatory bowel disease: Prevalence and diagnostic role. Gut 1992; 33:668-674. 
22 Lee JC, Lennard-Jones JE, Cambridge G: Antineutrophil antibodies in familial inflammatory bowel disease. Gastroenterology 1995;108: 428-433.

23 Annese V, Andreoli A, Andriulli A, Dinca R, Gionchetti P, Latiano A, Lombardi G, Piepoli A, Poulain D, Sendid B, Colombel JF: Familial expression of anti-Saccharomyces cerevisiae mannan antibodies in Crohn's disease and ulcerative colitis: A GISC study. Am J Gastroenterol 2001;96:2407-2412.

24 Glas J, Torok HP, Vilsmaier F, Herbinger KH, Hoelscher M, Folwaczny C: Anti-Saccharomyces cerevisiae antibodies in patients with inflammatory bowel disease and their firstdegree relatives: Potential clinical value. Digestion 2002;66:173-177.

25 Folwaczny C, Noehl N, Tschop K, Endres SP, Heldwein W, Loeschke K, Fricke H: Goblet cell autoantibodies in patients with inflammatory bowel disease and their first-degree relatives. Gastroenterology. 1997;113:101-106.

26 Folwaczny C, Noehl N, Endres SP, Heldwein W, Loeschke K, Fricke H: Antinuclear autoantibodies in patients with inflammatory bowel disease. High prevalence in first-degree relatives. Dig Dis Sci 1997;42:1593-1597.

27 Vermeire S, Joossens S, Peeters M, Monsuur F, Marien G, Bossuyt X, Groenen P, Vlietinck R, Rutgeerts P. Comparative study of ASCA (antiSaccharomyces cerevisiae antibody) assays in inflammatory bowel disease. Gastroenterology 2001;120:827-833.

28 Hoffman IE, Demetter P, Peeters M, De Vos M, Mielants H, Veys EM, De Keyser F: AntiSaccharomyces cerevisiae IgA antibodies are raised in ankylosing spondylitis and undifferentiated spondyloarthropathy. Ann Rheum Dis 2003;62:455-459.
29 Koh WH, Dunphy J, Dixey J, Calin A, McHugh NJ, Maddison PJ: Atypical antineutrophil cytoplasmic antibodies in patients with ankylosing spondylitis. Br J Rheumatol 1995; 34:695-696.

30 Weinerth JD, Stoffel MP, Csernok E, Gross WL: Are antineutrophil cytoplasmic antibodies associated with spondyloarthropathies? $\mathrm{Br} \mathrm{J}$ Rheumatol 1996;35:1032-1033.

31 Locht H, Peen E, Skogh T: Antineutrophil cytoplasmic antibodies in reactive arthritis. $\mathrm{J}$ Rheumatol 1995;22:2304-2306.

32 Gordon LK, Eggena M, Holland GN, Weisz JM, Braun J: pANCA antibodies in patients with anterior uveitis: Identification of a marker antibody usually associated with ulcerative colitis. J Clin Immunol 1998;18:264-271.

33 Lionetti P, Pupi A, Veltroni M, Fonda C, Cavicchi MC, Azzari C, Falcini F: Evidence of subclinical intestinal inflammation by $99 \mathrm{~m}$ technetium leukocyte scintigraphy in patients with HLA-B27-positive juvenile onset active spondyloarthropathy. J Rheumatol 2000;27: 1538-1541.

34 Smale S, Natt RS, Orchard TR, Russell AS, Bjarnason I: Inflammatory bowel disease and spondylarthropathy. Arthritis Rheum 2001;44: 2728-2736.

35 Vermeire S, Peeters M, Vlietinck R, Joossens S, Den Hond E, Bulteel V, Bossuyt X, Geypens B, Rutgeerts P: Anti-Saccharomyces cerevisiae antibodies (ASCA), phenotypes of IBD, and intestinal permeability: a study in IBD families. Inflamm Bowel Dis 2001;7:8-15.

36 Mielants H, De Vos M, Goemaere S, Schelstraete K, Cuvelier C, Goethals K, Maertens M, Ackerman C, Veys EM: Intestinal mucosal permeability in inflammatory rheumatic diseases. II. Role of disease. J Rheumatol 1991;18: 394-400.
37 Baeten D, De Keyser F, Mielants H, Veys EM: Immune linkages between inflammatory bowel disease and spondyloarthropathies. Curr Opin Rheumatol 2002;14:342-347.

38 Demetter P, Baeten D, De Keyser F, De Vos M, Van Damme N, Verbruggen G, Vermeulen S, Mareel M, Elewaut D, Mielants H, Veys EM, Cuvelier CA: Subclinical gut inflammation in spondyloarthropathy patients is associated with upregulation of the E-cadherin/catenin complex. Ann Rheum Dis 2000;59:211-216.

39 Demetter P, Van Huysse JA, De Keyser F, Van Damme N, Verbruggen G, Mielants H, De Vos M, Veys EM, Cuvelier CA: Increase in lymphoid follicles and leukocyte adhesion molecules emphasizes a role for the gut in spondyloarthropathy pathogenesis. J Pathol 2002;198: 517-522.

40 Van Damme N, De Vos M, Baeten D, Demetter P, Mielants H, Verbruggen G, Cuvelier C, Veys EM, De Keyser F: Flow cytometric analysis of gut mucosal lymphocytes supports an impaired Th1 cytokine profile in spondyloarthropathy. Ann Rheum Dis 2001;60:495-499.

41 Demetter P, De Vos M, De Keyser F, Van de Velde S, Baeten D, Van Damme N, Verbruggen G, Mielants H, Veys EM, Cuvelier CA Increased number of macrophages in noninflamed colon of patients with spondyloarthropathy, a human model of early Crohn's disease. Gastroenterology 2000; 118:A342.

42 May E, Marker-Hermann E, Wittig BM, Zeitz M, Meyer zum Buschenfelde KH, Duchmann $\mathrm{R}$ : Identical T-cell expansions in the colon mucosa and the synovium of a patient with enterogenic spondyloarthropathy. Gastroenterology 2000;119:1745-1755. 